\title{
KERAGAMAN SERANGGA PADA Oryza sativa $L$. DI KECAMATAN PILANGKENCENG DAN KECAMATAN KARE KABUPATEN MADIUN
}

\author{
Eni Nur Fadilah ${ }^{1}$, Cicilia Novi Primiani ${ }^{2}$ \\ ${ }^{1,2)}$ Program Studi Pendidikan Biologi, FPMIPA, IKIP PGRI MADIUN \\ e-mail: primianibiomipa@yahoo.co.id
}

\begin{abstract}
The research aims to identify the insects in rice plants in the district Pilangkenceng and Kare Madiun. Research method using qualitative descriptive and in accordance with what is on the field. Data were collected by observation. Insects captured in two ways: directly and using flay arrest of the net. The results showed that the insects found in rice plant in the district of Pilangkenceng order Orthoptera, Hemiptera, Odonata, Hymenoptera, Lepidoptera, Coleoptera and Diptera. Insects found in the District of Kare consists of the Order Orthoptera, Odonata, Lepidoptera, Coleoptera and Homoptera.
\end{abstract}

Keywords: insect diversity, identification, Oryza sativa L.

\section{PENDAHULUAN}

Madiun merupakan salah satu Kabupaten yang terletak di Provinsi Jawa Timur terdiri dari 15 Kecamatan, diantaranya adalah Kecamatan Pilangkenceng dan Kecamatan Kare. Kecamatan Pilangkenceng merupakan daerah yang terletak di daerah dataran rendah, oleh sebab itu Kecamatan Pilangkenceng termasuk daerah yang mempunyai suhu tinggi (panas). Kecamatan Kare merupakan daerah yang terletak di Kabupaten Madiun bagian selatan dan terletak di daerah dataran tinggi tepatnya berada di lereng Gunung Wilis, oleh sebab itu Kecamatan Kare merupakan salah satu kecamatan di Kabupaten Madiun yang mempunyai suhu rendah (dingin).

Penduduk Kecamatan Pilangkenceng dan Kecamatan Kare sebagian besar sebagai petani, tanaman padi (Oryza sativa $L)$ merupakan salah satu tanaman pangan yang banyak dibudidayakan oleh petani di Kecamatan Pilangkenceng dan Kecamatan Kare. Kebutuhan pangan padi tidak pernah surut, melainkan semakin bertambah setiap tahunnya (Hilman, 2010). Menghadapi kenyataan tersebut, para petani bekerja keras untuk meningkatkan produksi bahan pangan padi untuk mengimbangi kebutuhan pangan yang terus meningkat sesuai dengan pertumbuhan penduduk. Tanaman pertanian seringkali mendapat gangguan dari organisme pengganggu tanaman yang mengakibatkan menurunnya kualitas serta kuantitas produksi padi. Organisme pengganggu tanaman tersebut dikenal sebagai hama tanaman, salah satu organisme pengganggu pada tanaman padi adalah serangga (insecta).

Berdasarkan hasil penelitian Akmad et al. (2002) serangga yang banyak ditemukan sebagai organisme pengganggu tanaman padi adalah ordo Hemiptera, Homoptera dan Lepidoptera. Tidak semua ordo serangga merupakan organisme pengganggu tanaman, karena ada pula beberapa ordo serangga yang berperan sebagai predator bagi organisme pengganggu tanaman padi. Beberapa serangga yang berperan sebagai predator bagi serangga dipertanaman padi ditemukan dari ordo Coleoptera.

Serangga merupakan salah satu anggota dari phylum Arthropda disebut juga Heksapoda. Heksapoda berasal dari kata heksa yang berarti enam dan podos yang berarti kaki, jadi serangga merupakan hewan yang berkaki enam. Serangga beranggotakan 675.000 spesies yang tersebar di segala penjuru dunia (Jasin, 1992). Serangga adalah arthropoda yang memiliki penyesuaian terhadap kehidupan 
di darat dengan modifikasi dalam bentuk tubuh dan fisiologinya. Penyesuaian yang sedemikian jauh itu tidak lain karena adanya kemampuan untuk membatasi jumlah air yang hilang dari tubuhnya, hal itu disebabkan karena serangga (insecta) memiliki kutikula yang berlapis lilin sehingga menjadikan tubuhnya tahan terhadap air (Radiopoetro, 1991).

Menurut Cheliver dan Neguier dalam Hilman (2010) padi merupakan tanaman yang berasal dari dua benua. Tanaman padi jenis Oryza fatua Koenig dan Oryza sativa $L$ merupakan tanaman padi yang berasal dari benua Asia, sedangkan jenis padi lainnya seperti Oryza stapfii Roschev dan Oryza glaberrima Steund berasal dari Afrika Barat (Benua Afrika). Tanaman padi dapat tumbuh di daerah yang mempunyai temperatur sedang sampai tinggi dengan intensitas cahaya matahari yang panjang. Suhu rata-rata yang sesuai untuk kelangsungan hidup padi antara $68^{\circ}$ $100^{\circ} \mathrm{F}$ (Dhini, 2008).

Tujuan penelitian untuk mengidentifikasi serangga pada tanaman padi di Kecamatan Pilangkenceng dan Kecamatan Kare Kabupaten Madiun berdasarkan ciri-ciri morfologinya.

\section{METODE PENELITIAN}

Metode penelitian yang digunakan dengan pendekatan diskriptif observasional. Melalui observasi dapat dilakukan identifikasi terhadap insecta yang terdapat pada tanaman padi. Serangga yang diidentifikasi dapat ditangkap secara langsung maupun ditangkap dengan bantuan flay net (Haryono, 2007). Data yang digunakan adalah data identifikasi serangga pada tanaman padi (Oryza sativa $L)$. Data berupa data ciri-ciri morfologi yang meliputi panjang tubuh, warna tubuh, panjang pendeknya sungut dan ada tidaknya sayap. Sumber data dalam penelitian ini adalah serangga yang diperoleh dari lokasi penelitian yang berada di Kecamatan Pilangkenceng dan Kecamatan Kare Kabupaten Madiun.

Tahap-tahap penelitian terdiri dari tahap persiapan, tahap penangkapan, tahap identifikasi, dan tahap klasifikasi. Analisis data dilakukan secara diskriptif yang berupa hasil identifikasi serangga berdasarkan dari analisis kunci determinasi menggunakan berbagai sumber pendukung yang berupa buku identifikasi serangga karangan Borror et al., (1992).

\section{HASIL DAN PEMBAHASAN}

Serangga merupakan golongan hewan yang jumlahnya melebihi hewan daratan lainnya. Serangga dapat ditemukan di berbagai macam tempat, seperti daerah persawahan, perumahan, lautan, dan hutan. Serangga merupakan salah satu hewan yang memiliki kemampuan beradaptasi yang cukup tinggi, oleh sebab itu serangga dapat bertahan hidup baik di daerah dataran tinggi dengan suhu yang dingin maupun daerah dataran rendah dengan suhu yang panas sekalipun. Adapun serangga yang ditemukan di areal persawahan Kecamatan Pilangkenceng Kabupaten Madiun seperti pada Tabel 1. Serangga yang ditemukan di areal persawahan Kecamatan Kare terdapat pada Tabel 2.

Tabel 1 Serangga di Persawahan Kecamatan Pilangkenceng

\begin{tabular}{ll}
\multicolumn{1}{c}{ Nama Famili } & \multicolumn{1}{c}{ Ciri Spesifik } \\
\hline Copiphorinae & Ukuran tubuh $19 \mathrm{~mm}$, sayap-sayap depan bervariasi bentuknya, tetapi \\
& daerah kosta tanpa rangka-rangka sayap transversal. \\
& Permukaan dorsal permukaan tarsus pertam berlekuk disebelah lateral, duri \\
& prosternum biasanya ada, sayap-sayap depan kira-kira sama panjangnya \\
& dengan sayap belakang. Bagian anterior verteks berbentuk konis, kadang- \\
& kadang meruncing, meluas bagus di belakang ruas sungut dasar.
\end{tabular}


Lanjutan tabel 1

Carabidae

Berukuran sedang dengan panjang tubuh $18 \mathrm{~mm}$. Sungut relatif panjang dan beruas sebelas. pada sisi-sisi kepala antara mata dan dasar mandibel, klipeus tidak timbul secara lateral di belakang dasar-dasar sungut Antena atau sungut letaknya disebelah lateral. Kepala ukurannya lebih kecil dibandingkankan protonum. Abdomen berwarna hitam dan beruas lima. Sayap elytra berwarna hitam metalik dengan tortol berwarna orange pada bagian tengah sayap.

Acrididae

Bertubuh ramping dengan panjang tubuh $18 \mathrm{~mm}$. Serangga tersebut mempunyai wajah yang miring ke belakang. Abdomen berwarna hijau muda dan beruas 8. Sayap berwarna coklat dan femur berwarna hijau kekuningan.

Reduviidae Berukuran sedang dengan panjang tubuh $21 \mathrm{~mm}$. Ruas tungkai yang terakhir adalah kuku-kuku tarsus. Bersungut panjang dan mempunyai abdomen berwarna coklat keputih-putihan dan beruas 6 serta melebar ke arah samping. Mempunyai proboscis panjang $4 \mathrm{~mm}$. Kepala memanjang, bagian belakang mata berbentuk seperti leher.

Gryllotalpidae Panjang tubuh $23 \mathrm{~mm}$, tungkai depan lebih besar bila dibandingkan tungkaitungkai belakang. Bersayap kecil dan berwarna coklat. Sayap lebih pendek dari panjang tubuh serangga tersebut. Bersungut pendek dan abdomen berwarna coklat dan beruas 8 .

Pyralidae

Panjang tubuh $12 \mathrm{~mm}$. Bersungut pendek dan abdomen berwarna putih kekuningan dengan lima ruas. Sayap depan lebih berbentuk segitiga bila dibandingkan sayap belakang. Sayap berwarna kuning dengan satu bintik hitam ditengah pada masing-masing sayap

Gomphidae

Panjang tubuh $51 \mathrm{~mm}$, gelambir median labium tidak berlekuk Mempunyai stigma yang panjangnya $4 \mathrm{~mm}$. Tubuh berwarna hitam dengan spot pita yang kekuningan. Bersayap transparan, pangkal sayap belakang lebih besar dibandingkan pangkal sayap depan. ekornya berbentuk gada.

Coenagrionidae Capung jarum dengan panjang tubuh $29 \mathrm{~mm}$. Serangga memiliki sayap depan dan sayap belakang yang serupa bentuknya dan keduanya menyempit pada bagian pangkalnya. Abdomen berwarna biru muda dengan garis-garis hitam mulai dari ujung hingga pangkal abdomen

Alydae

Serangga bertubuh ramping panjang tubuh $14 \mathrm{~mm}$. Abdomen berwarna hijau muda dan beruas lima. Bersayap transparan dan berwarna coklat keemasan. Memiliki antena dan tungkai yang relatif panjang. Lebar kepala hampir sama dengan lebar protonum. Ditemukan pada tanaman padi sudah mulai masuk fase generatif.

Tabanidae Berukuran sedang panjang tubuh $14 \mathrm{~mm}$. Bersungut pendek dan sungut berada pada tengah kepala bagian bawah. Bersayap transparan dengan garis coklat pada bagian tepinya. Costa berakhir sebelum ujung-ujung sayap, cabang radius agak bergerombol bersama dekat dengan batas kosta. Postskutellum bagus berkembang, calypter-calypter besar dan kelihatan. Tergit abdomen pertama dengan lekuk di tengah batas posterior dan dengan sutura median.

Acrididae Berukuran sedang dengan panjang tubuh $19 \mathrm{~mm}$. Mempunyai wajah miring ke belakang bila dilihat dari arah lateral. Bersungut pendek. Bersayap coklat dengan bercak-bercak kuning keemasan. Sayap berukuran lebih panjang dari panjang tubuh. Abdomen berwarna kecoklatan dengan 7 ruas

Pentatomidae Bertubuh sedang, panjang tubuh $16 \mathrm{~mm}$. Protonum dibatasi secara lateral, dasarnya selebar dasar elytra, kepala sangat lebih sempit daripada protonum Tubuh berbentuk segilima dan berwarna hijau muda, bersungut pendek dan memiliki abdomen yang berwarna hijau kecoklatan dan beruas lima. Tarsi 3 ruas, sternum toraks biasanya tanpa tonjolan longitudinal.Mengeluarkan bau tidak enak ketika merasa terganggu. 
Tabel 2 Serangga di Persawahan Kecamatan Kare

\begin{tabular}{|c|c|}
\hline Nama Famili & Ciri Spesifik \\
\hline Pyralidae & $\begin{array}{l}\text { Serangga berukuran kecil dengan panjang } 0,9 \mathrm{~mm} \text {. Bersungut pendek dengan } \\
\text { abdomen beruas enam. Sayap berwarna kuning dengan bercak-bercak merah } \\
\text { jambu. }\end{array}$ \\
\hline Satyridae & $\begin{array}{l}\text { Panjang tubuh } 17 \mathrm{~mm} \text {, bersungut pendek dengan bagian ujung yang } \\
\text { menggembung dan tubuh berwarna hitam, sungut menggembung pada bagian } \\
\text { ujung tetapi tidak secara jelas menjendol. Sayap berwarna orange dengan spot- } \\
\text { spot hitam seperti mata, sayap depan agak segitiga, Abdomen berwarna coklat } \\
\text { kekuningan dengan delapan ruas. Tidak ada rangka anal } 3 \text { pada sayap depan, } \\
\text { rangka sayap anal } 1 \text { dan } 2 \text { tidak kelihatan bercabang pada bagian dasar. }\end{array}$ \\
\hline Tettigoniidae & $\begin{array}{l}\text { Serangga berukuran sedang dengan panjang tubuh } 14 \mathrm{~mm} \text {. Sayap berwarna } \\
\text { kuning kecoklatan. Merupakan serangga betina yang dapat diketahui dari } \\
\text { ovipositornya yang panjangnya mencapai } 15 \mathrm{~mm} \text {. Memiliki antena yang relatif } \\
\text { panjang. }\end{array}$ \\
\hline Coccinellidae & $\begin{array}{l}\text { Berukuran kecil, panjang tubuh } 0,7 \mathrm{~mm} \text {. Tubuh berbentuk bulat telur dengan } \\
\text { kepala yang tersembunyi dibawah protonum yang meluas. Mempunyai antena } \\
\text { yang tergolong pendek. Elytra berwarna merah cerah dengan spot-spot hitam. } \\
\text { Banyak ditemukan di ujung helaian daun padi. }\end{array}$ \\
\hline Libellulidae & $\begin{array}{l}\text { Serangga dengan tubuh yang relatif besar panjang } 47 \mathrm{~mm} \text {. Pangkal sayap } \\
\text { belakang lebih lebar dibandingkan sayap depan dan terdapat bercak-bercak } \\
\text { berwarna orange pada bagian pangkal sayap. Panjang stigma sayap adalah } 3 \\
\text { mm. Tepi belakang mata majemuk lerus dengan gelambir yang sangat kecil, } \\
\text { yang jantan tanpa gelambir kecil pada sisi ruas abdomen yang kedua dengan } \\
\text { tepi bagian dalam "kaki" terbentuk bagus. }\end{array}$ \\
\hline Cicadellidae & $\begin{array}{l}\text { Berukuran kecil dengan panjang } 0,4 \mathrm{~mm} \text {. Protonum tidak meluas ke belakang. } \\
\text { Tubuh berwarna hijau daun dan pada sayap depan terdapat bercak-bercak hitam } \\
\text { di bagian tengah dan pada bagian ujungnya. Abdomen berwarna coklat dan } \\
\text { kepala berwarna lebih gelap. }\end{array}$ \\
\hline
\end{tabular}

Penelitian telah dilakukan pada dua tempat dengan suhu yang berbeda, namun ternyata serangga yang ditemukan dari Kecamatan Pilangkenceng dan Kecamatan Kare tidak jauh berbeda. Berdasarkan lokasi penelitian di Kecamatan Pilangkenceng dan Kecamatan Kare ditemukan serangga ordo Orthoptera, Odonata, Lepidoptera, dan Coleoptera. Meskipun ada beberapa ordo yang tidak ditemukan pada salah satu tempat, seperti ordo Hemiptera dan ordo Diptera yang hanya ditemukan di pertanaman padi di Kecamatan Pilangkenceng, sedangkan Ordo Homoptera hanya ditemukan di persawahan di Kecamatan Kare. Umur tanaman padi menjadi faktor utama yang menyebabkan adanya pebedaan ordo serangga seperti ordo Homoptera yang hanya ditemukan pada tanaman padi di Kecamatan Kare.

Tanaman padi di Kecamatan Kare merupakan tanaman padi yang masih termasuk dalam fase vegetatif, yaitu tanaman padi yang masih terdiri dari akar, batang dan helaian daun. Fase vegetatif menyebabkan pada tanaman banyak ditemukan serangga ordo homoptera yang merupakan serangga herbivora, yang banyak ditemukan pada batang-batang tanaman padi. Serangga ordo homoptera tersebut merupakan serangga yang banyak ditemukan sebagai hama tanaman dan biasanya keberadaan serangga tersebut menyebabkan tanaman menjadi kerdil serta daun berbercak kuning kecoklatan (Christiana, 1991: 86).

Tanaman padi di Kecamatan Pilangkenceng merupakan tanaman padi yang sudah masuk dalam fase generatif, yaitu tanaman padi yang terdiri dari akar, batang, helaian daun dan malai. Umur tanaman padi di Kecamatan Pilangkenceng yang sudah memasuki fase generatif menyebabkan tanaman padi banyak 
ditemukan serangga ordo Hemiptera dan Diptera. Serangga-serangga banyak ditemukan pada malai-malai tanaman padi, sehingga dapat diambil kesimpulan bahwa serangga ordo Hemiptera dan Diptera hanya ditemukan pada tanaman padi yang sudah masuk dalam fase generatif atau tanaman padi yang sudah mulai berbunga atau berbuah.

\section{SIMPULAN}

Berdasarkan data hasil identifikasi serta pembahasan dapat diambil kesimpulan bahwa serangga yang ditemukan dari pertanaman padi di Kecamatan Pilangkenceng terdiri atas ordo Orthoptera, Hemiptera, Odonata, Hymenoptera, Lepidoptera, Coleoptera dan Diptera. Serangga yang ditemukan dari pertanaman padi di Kecamatan Kare adalah Ordo Orthoptera, Odonata, Lepidoptera, Coleoptera dan Homoptera. Adanya perbedaan ordo serangga yang ditemukan tidak dipengaruhi oleh perbedaan suhu dari masing-masing tempat, melainkan karena perbedaan umur tanam padi. Hasil penelitian dapat digunakan sebagai referensi bagi masyarakat khususnya petani untuk memperhatikan jenis serangga pada setiap fase pertumbuhan padi, sehingga dapat digunakan sebagai pertimbangan dalam melakukan pengendalian terhadap serangga.

\section{DAFTAR PUSTAKA}

Akmad R, Damayanti B, Hermanu T. 2002. Keanekaragaman Serangga pada Lahan Persawahan-Tepian Hutan: Indikator untuk Kesehatan Lingkungan (online). (journal.ipb.ac.id). Diakses 2 April 2012)

Hilman. C. 2010. Hubungan Karakteristik Petani Dengan Sumber Dan Kebutuhan Informasi Untuk Pengembangan Agribisnis (online). (http://repository.ipb.ac.id). Diakses 6 April 2012).
Christiana L. 1991. Kunci Determinasi Serangga. Yogyakarta: Kanisius

Dhini, Y. R. 2008. Pengaruh Tinggi Genangan Terhadap Pertumbuhan Gulma dan Produksi Padi Hibrida (Oryza sativa) (online). (http://repository.ipb.ac.id)

Diakses 10 April 2012)

Haryono, S. 2007. Studi Keanekaragaman Serangga Pada Perkebunan Apel Organik Dan Anorganik (Online).(http://_lib.uinmalang.ac.id) Diakses 25 Maret 2012)

Jasin, M. 1992. Zoologi Invertebrata Untuk Perguruan Tinggi. Surabaya: Sinar Wijaya

Radiopoetro. 1991. Zoologi. Jakarta: Erlangga

Borror, D.J. Triplehorn, C.A., dan Johnson, N.F. 1992. Pengenalan Pelajaran Serangga Edisi Keenam. Alih bahasa: Soetiyono Partosoedjono. Yogyakarta: Gadjah Mada University Press 